\title{
Molecular Detection of Bovine Leukocytic Anaplasma Species in Isfahan, Iran
}

\author{
Vahid Noaman ${ }^{1 *}$, Abdolreza Nabinejad ${ }^{1}$, Amirhossein Shahmoradi ${ }^{1}$, Saeid Esmaeilkhanian ${ }^{2}$ \\ ${ }^{1}$ Veterinary Research Department, Isfahan Agriculture and Natural resources Research and Education Center, AREEO, Isfahan, Iran. \\ ${ }^{2}$ Animal Science Research Institute of Iran, Agricultural Research, Education and Extension Organization (AREEO), Karaj, Iran.
}

Received: 2 Jan 2016

Revised : 5 Feb 2016

Accepted: 1 Mar 2016

Corresponding Author:

Vahid Noaman

Veterinary Research Department,

Isfahan Agriculture and Natural resources Research and Education Center, AREEO, Isfahan, Iran. Phone: +983137885460

E-mail: vnoaman@gmail.com

\begin{abstract}
Background: A. bovis and A. phagocytophilium are leukocytotropic agents of bovine anaplasmosis. They are obligate intracellular bacteria that can infect and cause Anaplasmosis in human and animals. Therefore, this study was carried out to detect A. bovis and A. phagocytophilum in naturally infected dairy cattle in Isfahan using molecular techniques.

Materials and Methods: In this study a total of 209 blood samples were collected from cattle in central part of Iran (Isfahan). The presence of A. bovis and A. phagocytophilium were examined by species-specific nested polymerase chain reaction (nPCR) based on 16S rRNA gene.

Results: Out of the 209 cattle examined, $4(1.99 \%)$ and $2(1 \%)$ were found positive for A. bovis and A. phagocytophilium by nPCR, respectively.

Conclusion: These data showed a relatively low prevalence of leukocytic Anaplasma infection in cattle in central part of Iran.
\end{abstract}

Keywords: A. bovis; A. phagocytophilium; nested-PCR; 16S rRNA gene; Iran

Please cite this article as: Noaman V, Nabinejad A, Shahmoradi A, Esmaeilkhanian S. Molecular Detection of Bovine Leukocytic Anaplasma Species in Isfahan, Iran. Res Mol Med. 2016; 4 (2): 47-51

\begin{abstract}
Introduction
Anaplasmosis is a tick-born disease of cattle and other ruminants caused by species of the genus Anaplasma (Rickettsiales: Anaplasmataceae) (1). Four species including A. marginale, A. centrale, A. bovis, and $A$. phagocytophilium are well recognized in cattle (2). Among these species, A. bovis and A. phagocytophilium are leukocytic Anaplasmawhich infect monocytes and granulocytes, respectively.

A. bovis is a monocytotropic Anaplasma sp. and it was first described in 1936 during experiments of Theileria sp. transmission, in which Hyalomma sp. ticks from Iran was fed to French cattle. A. bovis casuses fever, anemia, weight loss and rarely abortion and death in cattle of tropical and subtropical regions of the world. Survivors are lifelong carriers (3).

A. phagocytophilum is a zoonotic, tick borne rickettsial pathogen. This organism has long been recognized as a veterinary agent, but in 1994, first human infection was reported A. phagocytophilum has been considered as an emerging pathogen of public health importance (4-6).Tick borne fever (TBF) in cattle caused by $A$. phagocytophilum is characterized by high fever, reduced milk yield,inclusions neutrophils,
\end{abstract}

leukopenia, abortions and reduced fertility. Most of the time, A. phagocytophilum infections are subclinical and rarely causing death unless complexed with other infections (7).

A. phagocytophilum is transstadially transmitted by the tick vectors. Ixodes ricinus has been found to be the main vector of A. phagocytophilum in Europe (8, 9). A. phagocytophilum has been also detected in Ixodes ricinus in Iran (10). However, other ticks have also been associated with $A$. phagocytophilum transmission (7).

Several hard tick species are distributed in Iran and they are the most important ectoparasites of cattle in central parts of Iran. Although more is known about ticks as responsible for the transmission of several rickettsial pathogens to cattle but there is little knowledge about leukocytic anaplasmosis in cattle in Iran. A. phagocytophilum and A. bovis were reported for the first time in carrier cattle from central part of Iran by PCR $(11,12)$.

Due to change in ecological condition and vector population a regular monitoring for the definition and prevalence of pathogen is important. To update this 
information, a surveillance study was carried out to detect A. bovis and A. phagocytophilum in naturally infected dairy cattle in Isfahan by molecular techniques.

\section{Materials and Methods \\ Collection of blood samples}

The study was carried out in cattle farms in seven counties in Isfahan province, central Iran. The province experiences a moderate and dry climate, ranging from $10.6{ }^{\circ} \mathrm{C}$ in winter to $40.6{ }^{\circ} \mathrm{C}$ in summer. The average annual temperature has been recorded as $16.7^{\circ} \mathrm{C}$, and the annual rainfall on average has been reported as $116.9 \mathrm{~mm}$. The villages and flocks were selected using stratified random sampling. Blood samples were collected from the jugular vein of 209 apparently healthy cattle. Five hundred micro liters of each sample was taken in tubes containing the anticoagulant ethylene diamine tetra-acetic acid (EDTA). The blood samples were stored at $-20{ }^{\circ} \mathrm{C}$ until DNA extraction.

\section{DNA extraction}

DNA was extracted using the DNA isolation kit [Molecular Biology System Transfer (MBST), Iran] according to the manufacturer's instructions. Briefly, $50 \mu \mathrm{l}$ of blood samples was lysed in $180 \mu \mathrm{l}$ lysis buffer and the proteins were degraded with $20 \mu \mathrm{l}$ proteinase $\mathrm{K}$ for $10 \mathrm{~min}$ at $55^{\circ} \mathrm{C}$. After adding $360 \mu \mathrm{l}$ Binding buffer and incubation for $10 \mathrm{~min}$ at $70{ }^{\circ} \mathrm{C}$, $270 \mu \mathrm{l}$ ethanol $(96 \%)$ was added to the solution and after vortexing, the complete volume was transferred to the MBST-column. The MBST-column was first centrifuged, and then washed twice with $500 \mu \mathrm{l}$ washing-buffer. Finally, DNA was eluted from the carrier using $100 \mu$ l Elution buffer. The amount of extracting DNA and its purity was measured by optical density 260 (OD260) and the ratio of OD260 to OD280, respectively. In addition the extracted DNA was analyzed on agarose gel before use.

Table 1. List of primers designed based on 16S rRNA gene

\begin{tabular}{|c|c|c|c|}
\hline Name of primer & $\begin{array}{l}\text { Publication references and } \\
\text { Accession No. in GenBank }\end{array}$ & Nucleotid sequences & PCR-product \\
\hline Anaplasma Phagocytophilum sense & \multirow{2}{*}{ M73220 Barlough et al. 1996} & 5GTCGAACGGATTATTCTTTATAGCTTGC3' & \multirow{2}{*}{$926 \mathrm{bp}$} \\
\hline Anaplasma Phagocytophilum Antisense & & 5СССТTCCGTTAAGAAGGATCTAATCTCC3' & \\
\hline Anaplasma bovis sense & \multirow{2}{*}{ U03775 Kawahara et al.2006 } & 5CTCGTAGCTTGCTATGAGAAC3' & \multirow{2}{*}{$551 \mathrm{bp}$} \\
\hline Anaplasma bovis Antisense & & 5'TCTCCCGGACTCCAGTCTG3' & \\
\hline
\end{tabular}

Polymerase chain reaction (PCR) and Specific nested PCR (nPCR)

The first PCR was performed using the universal primers fD1(5'-AGAGTTTGATCCTGGCTCAG-3') and Rp2 (5'-ACGGCTACCTTGTTACGACTT-3'), in $50 \mu \mathrm{l}$ total volume including one time PCR buffer, 2.5 U Taq Polymerase (Cinnagen, Iran), $2 \mu \mathrm{l}$ of each primer (fD1/ Rp2, $20 \mu \mathrm{M}$, Cinnagen), $200 \mu \mathrm{M}$ of each dATP, dTTP, dCTP and dGTP (Cinnagen), 1.5 $\mathrm{mM} \mathrm{MgCl} 2$ and $100-500 \mathrm{ng}$ extracted DNA in automated thermocycler (T100 Thermal Cycler, Bio$\mathrm{Rad}$ ) using the following program: 5 min incubation at $95{ }^{\circ} \mathrm{C}$ to denature double strand DNA, 40 cycles of $45 \mathrm{~s}$ at $94{ }^{\circ} \mathrm{C}$ (denaturing step), $45 \mathrm{~s}$ at $55{ }^{\circ} \mathrm{C}$ (annealing step) and $1.5 \mathrm{~min}$, at $72{ }^{\circ} \mathrm{C}$ (extension step) (13).

Specific internal primer sets targeting the hyper variable region (V1) of the $16 \mathrm{~S}$ rRNA were used to detect $A$. bovis and A. phagocytophilum (14, 15). Specific nPCR reactions were performed directly with $2 \mu \mathrm{l}$ of the primary PCR product separately. The nPCR for A. bovis was performed in $50 \mu$ total volume, including one time PCR buffer, 1.25U Taq Polymerase (Cinnagen, Iran), $1 \mu \mathrm{l}$ of each primer (20 $\mu \mathrm{M}$, Cinnagen), $200 \mu \mathrm{M}$ of each dATP, dTTP, dCTP and dGTP (Fermentas) and $1.5 \mathrm{mM} \mathrm{MgCl} 2$ in automated Thermocycler (MWG, Germany) using the following program: $5 \mathrm{~min}$ incubation at $95{ }^{\circ} \mathrm{C}$ to denature double strand DNA, 35 cycles of $45 \mathrm{~s}$ at 94 ${ }^{\circ} \mathrm{C}$ (denaturing step), $45 \mathrm{~s}$ at $56{ }^{\circ} \mathrm{C}$ (annealing step) and $45 \mathrm{~s}$ at $72{ }^{\circ} \mathrm{C}$ (extension step). Finally, PCR was completed with the additional extension step for 10 min.

The nPCR conditions for A. phagocytophilum were the same as that described for the A. bovis, except the annealing temperature which was $50{ }^{\circ} \mathrm{C}$. The nPCR products were analyzed on $2 \%$ agarose gel in 0.5 times Tris-Borate-EDTA buffer and visualized using ethidium bromide and UV-transeluminator. The primers are listed in Table 1. 


\section{Results}

Analysis of blood samples by PCR and Specific nested PCR

PCR analysis of the isolated DNA from 200 blood samples using primers fD1/ Rp2 revealed an expected PCR product with approximately 1468bp in length from the 16SrRNA gene.

Detection of $A$. bovis was performed using specific primers designed from the nucleotide sequences of A. bovis hyper variable region of the abovementioned gene.

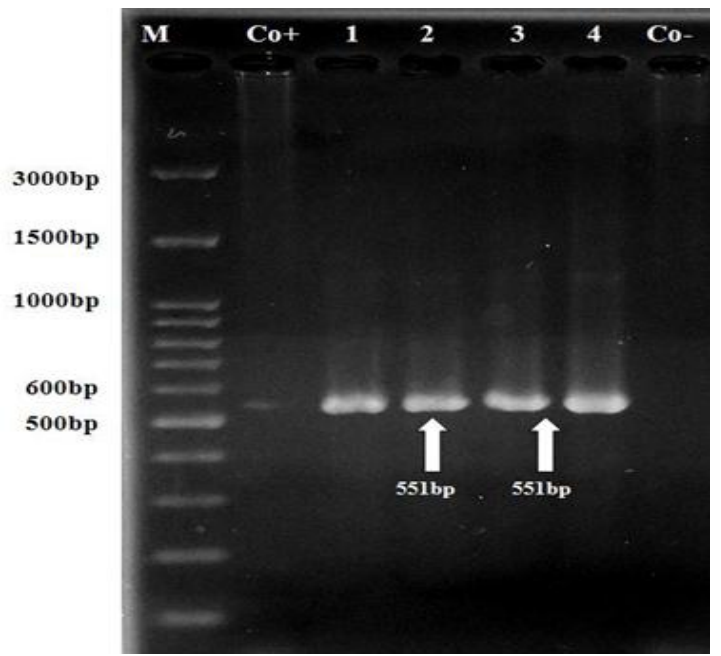

Figure 1. Specific nested-PCR for A. bovis. The expected size (551 bp) is indicated (lanes 1 to 4 ). $\mathrm{Co}^{+}$and $\mathrm{Co}$ - are positive and negative controls, respectively. $\mathrm{M}=$ Marker.

An expected PCR product of 551bp was amplified from the first PCR products by specific A. bovis primers (Figure 1). nPCR analysis of the primary PCR products with these primers revealed expected PCR product in $1.99 \%(4 / 209)$ of the blood samples.

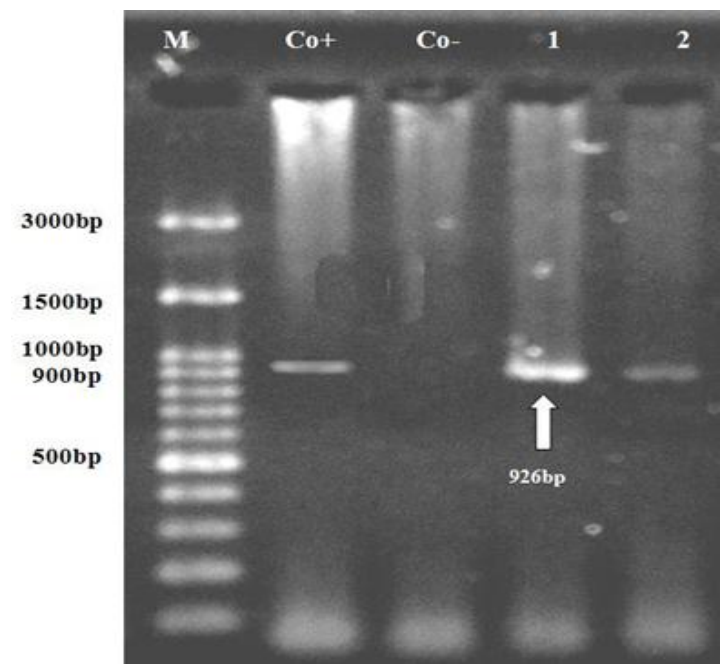

Figure 2. Specific nested-PCR for A. phagocytophilum. The expected size (926 bp) is indicated (lanes 1 and 2). $\mathrm{Co}^{+}$and $\mathrm{Co}-$ are positive and negative controls, respectively. $\mathrm{M}=$ Marker.
Detection of A. phagocytophilum was performed using specific primers designed from the nucleotide sequences of $A$. phagocytophilum hyper variable region of the above mentioned gene. Amplification of PCR products with primers showed an expected PCR product with 926 nucleotides in length (Figure 2). nPCR analysis of the primary PCR products with these primers revealed expected PCR product in $1 \%$ $(2 / 209)$ of the blood samples.

\section{Discussion}

Until now, five species of Anaplasma had been recognized in iranian cattle and sheep by molecular methods includes: A. marginale, A. centrale, A. phagocytophilium, A. bovis and A. ovis $(11,12,16-$ 19).

The 16S rRNA gene of Anaplasma spp. has a small hyper variable region; its nucleotide sequence has been used for the differentiation of Anaplasma spp. from each other (1, 20-22). Because of high sequence similarity among hyper variable region (V1) of $16 \mathrm{~S}$ rRNA gene, designing of species-specific primers based on 16S rRNA of A. marginale, A. centrale (South Africa strain) and A. ovis is impossible (11) but hyper variable regions of the 16S rRNA gene of $A$. bovis and $A$. phagocytophilum have enough different nucleotid sequence for designing speciesspecific primers and differentiation of these species from other Anaplasma spp. Therefore, in this study we designed species-specific primers based on $16 \mathrm{~S}$ rRNA for molecular detection of $A$. bovis and $A$. phagocytophilum.

Although Donatine and Lestoquard (1936) have reported the presence of $A$. bovis in blood of French cattle during experiments of Theileria sp. transmission by Iranian Hyalomma sp. ticks, there is little information concerning animal reservoirs of $A$. bovis in Asia (3). A. bovis DNA has recently been detected in wild deer (15) and cattle in an Asian country (Japan) (23).

In the present study $A$. bovis were identified by specific nPCR in $1.99 \%(4 / 209)$ of the blood samples. Using specific primers based on 16S rRNA gene, Noaman et al. showed that $2.66 \%$ of cattle blood samples were A. bovis positive (12). The present data indicates the low infection rate of cattle in central parts of Iran with A. bovis. Pathogenicity of A. bovis is already recognized and usually associated with subclinical infection; its principal manifestations include fever, lymphadenopathy, depression and loss of conditioning (24). In the present study, no clinical signs were recorded in the positive cattle. Jilintai et al. in a molecular survey showed that of the 78 cattle examined, $12(15 \%)$ tested positive for infection by A. bovis and no clinical symptoms were recorded in the positive cattle and morula were not detected in 
blood smears (25). Monocytes generally comprise less than $1 \%$ of all leukocytes in circulating blood, therefore, few infected cells would be present on a blood smear and despite careful observation of blood smears of these cattle, morulae were not detected in blood smears.

A. bovis has since been described in cattle and buffalo from Africa, the Middle East, and South America and Hyalomma spp., Rhipicephalus appendiculatus and Amblyomma variegatum have been proven to be vectors of $A$. bovis in African countries (26, 3). Hyalomma species are the most dominant tick species of cattle in Zagros mountainous areas in Iran (27) therefore, Hyalomma spp. may be an epidemiologically important tick species with respect to $A$. bovis infection of cattle in this area.

Our results showed that $1 \%(2 / 209)$ of the blood samples were A. phagocytophilum positive by specific primers based on $16 \mathrm{~S}$ rRNA gene. We have previously shown that $1.33 \%$ blood samples were A. phagocytophilum positive by specific primers based on 16S rRNA gene (11). In Asia the first molecular detection of $A$. phagocytophilum in wild deer and cattle was reported by Kawahara et al. (2006) and Ooshiro et al. (2008) from Japan (15, 23). A. phagocytophilum have been detected by PCR in mammals and ticks in nearly all European countries $(8,28)$. Mammals are presumed to play a crucial role in the maintenance and propagation of $A$. phagocytophilum in nature (29). A. phagocytophilum has been found to persist in species such as sheep, horse, dog, red deer, and cattle. Movement of persistent infected individuals may contribute to the spread of variants between geographical areas (7). Ixodes ricinus is the main vector of $A$. phagocytophilum in Europe (8). A. phagocytophilum has been also detected in Ixodes ricinus in Iran (10) which is also associated with other ticks, such as Haemaphysalis punctata, I. persulcatus, I. trianguliceps and Rhipicephalus sanguinus, but the epidemiological importance of these findings remains to be determined (7). Ixodes ricinus is only found in forest area next to the Caspian Sea. Hyalomma anatolicum, Hyalomma marginatum, Rhipicephalus sanguinus and Rhipicephalus bursa are dominant species of tick on cattle in central part of Iran (Isfahan province). In Asia A. phagocytophilum have been detected by PCR in Haemaphysalis longicornis (15) Hyalomma marginatum, Rhipicephalus turanicus, and Boophilus kohlsi (30), therefore, Hyalomma marginatum and Rhipicephalus sanguinus might be important vector ticks of this Anaplasma sp. in central part of Iran.

The results of present study confirm the low prevalence of A. bovis and A. Phagocytophilum in central part of Iran. To control the anaplasmosis we still have to determine the transmitting vectors, animal reservoirs and pathogenesis of $A$. bovis and $A$. phagocytophilum in animals and human in Iran.

\section{Acknowledgements}

This study was supported by National project No. 038-18-90016/9 of the Agricultural Research, Education and Extension Organization (AREEO), Iran. The authors are thankful to Razi Vaccine \& Serum Research Institute (RVSRI), Karaj, Iran and Veterinary Research Department, Isfahan Agriculture and Natural resources Research and Education Center, AREEO, Isfahan, Iran for funding the research.

\section{Conflict of interest}

The authors declare that they have no conflict of interest in this article.

\section{Author Contributions}

All authors have made substantial contributions to the conception and design of the study, doing the experiments, acquisition or statistical analysis and interpretation of data. All authors also contributed in final approval of the version of manuscript which to be submitted.

\section{Support/Funding}

This study was supported by National project No. 038-18-90016/9 of the Agricultural Research, Education and Extension Organization (AREEO), Iran.

\section{References}

1. Aubry P, Geale DW. A review of bovine anaplasmosis. Transbound Emerg Dis. 2011; 58(1):1-30. PMID: 21040509

2. Inokuma H. Vectors and reservoir hosts of Anaplasmataceae. In: Raoult D, Parola P, eds. Rickettsial Diseases. Taylor \& Grancis Group LLC, New York. 2007; 199-212.

3. Harrison A, Bastos AD, Medger K, Bennett NC. Eastern rock sengis as reservoir hosts of Anaplasma bovis in South Africa. Ticks Tick Borne Dis. 2013; 4(6): 503-505. PMID: 24050934

4. Dumler JS, Choi KS, Garcia-Garcia JC, Barat NS, Scorpio DG, Garyu JW, Grab DJ, Bakken JS. Human granulocytic anaplasmosis and Anaplasma phagocytophilum. Emerg Infect Dis. 2005; 11(12): 1828-34. PMID: 16485466

5. Woldehiwet Z. The natural history of Anaplasma phagocytophilum. Vet Parasitol. 2010; 167(2): 108-122. PMID: 19811878

6. Stuen S, Granquist EG, Silaghi C. Anaplasma phagocytophilum - a widespread multi-host pathogen with highly adaptive strategies. Front Cell Infect Microbiol. 2013; 3: 31. PMID: 23885337

7. Stuen S. Anaplasma phagocytophilum - the most widespread tick-borne infection in animals in Europe. Vet Res Commun. 2007; 31(Suppl. 1): 79-84. PMID: 17682851 
8. Chmielewska-Badora J, Zwolinski J, Cisak E, Wojcik-Fatla A, Buczek A, Dutkiewicz J. Prevalence of Anaplasma phagocytophilum in Ixodes ricinus ticks determined by polymerase chain reactionwith two pairs of primers detecting $16 \mathrm{~S}$ rRNA and ankA genes. Ann Agric Environ Med. 2007; 14: 281-5. PMID: 18247465

9. Stuen S, Oppegaard AS, Bergstrom K, Moum T. Anaplasma phagocytophilum infection in North Norway. The first laboratory confirmed case. Acta Vet Scand. 2005; 46(3):167-71. PMID: 16261930

10. Bashiribod H, Kazemi K, Eslami G, Bigdeli S, Bandehpour M, Rahbarian N, et al. First molecular detection of Anaplasma phagocytophilum in Ixodes ricinus ticks in Iran. J Med S Aci. 2004; 4(4): 282-6.

11. Noaman V, Shayan P. Molecular detection of Anaplasma phagocytophilum in carrier cattle of Iran - first documented report. Iran J Microbiol. 2009; 1(2): 37-42.

12. Noaman V, Shayan P. Molecular detection of Anaplasma bovis in cattle from central part of Iran. Vet Res Forum. 2010; 1: 117-22.

13. Weisburg WG, Barns SM, Pelletier DA. 16S ribosomal DNA amplification for phylogenetic study. J Bacteriol. 1991; 173: 697703. PMID: 1987160

14. Barlough JE, Madigan JE, DeRock E, Bigornia L. Nested polymerase chain reaction for detection of Ehrlichia equi genomic DNA in horses and ticks (Ixodes pacificus). Vet parasitol. 1996; 63(3): 319-29. PMID: 8966998

15. Kawahara M, Rikihisa $Y$, Lin Q, Isogai E, Tahara K, Itagaki A, et al. Novel genetic variants of Anaplasma phagocytophilum, Anaplasma bovis, Anaplasma centrale, and a novel Ehrlichia sp. in wild deer and ticks on two major islands in Japan. Appl Environ Microbiol. 2006; 72: 1102-109. PMID: 16461655

16. Noaman V. Report of Anaplasma centrale (Amori strain) in cattle in Iran [Persian]. Pajouhesh-Va-Sazandegi Vet J. 2013; 98 26-29.

17. Noaman V, Shayan P. A new PCR-RFLP method for detection of Anaplasma marginale based on 16S rRNA. Vet Res Commun 2010; 34(1): 43-50. PMID: 20013050

18. Noaman V, Shayan P, Amininia N. Molecular diagnostic of Anaplasma marginale in carrier cattle. I J Parasitol. 2009; 4(1): 318.

19. Noaman V, Shayan P, Shahmoradi AH. Detection of Anaplasma ovis based on 16S rRNA gene by PCR-RFLP in sheep from central part of Iran. J Vet Med Lab. 2009; 1: 27-7.
20. Aktas M, Altay K, Dumanli N. Molecular detection and identification of Anaplasma and Ehrlichia species in cattle from Turkey. Ticks Tick Borne Dis. 2011; 2(1):62-5. PMID: 21771539

21. Noaman V. Discrimination between Anaplasma marginale and Anaplasma ovis by PCR-RFLP. World Appl Sci J. 2013; 21(2): 190-95.

22. Molad T, Mazuz ML, Fleiderovitz L, Fish L, Savitsky I, Krigel $\mathrm{Y}$, et al. Molecular and serological detection of A. centrale- and A.marginale-infected cattle grazing within an endemic area. Vet Microbiol. 2006; 113: 55-62. PMID: 16300909

23. Ooshiro M, Zakimi S, Matsukawa Y, Katagiri Y, Inokuma H. Detection of Anaplasma bovis and Anaplasma phagocytophilum from cattle on Yonaguni Island, Okinawa, Japan. Vet Parasitol. 2008; 154: 360-4. PMID: 18468796

24. Ben Said M, Belkahia H, Karaoud M, Bousrih M, Yahiaoui M, Daaloul-Jedidi M, et al. First molecular survey of Anaplasma bovis in small ruminants from Tunisia. Vet Microbiol. 2015; 179(3): 322-6. PMID: 26088935

25. Jilintai Seino-N, Hayakawa D, Suzuki M, et al. Molecular survey for Anaplasma bovis and Anaplasma phagocytophilum infection in cattle in a pastureland where sika deer appear in Hokkaido, Japan. Jpn J Infect Dis. 2009; 62(1): 73-5. PMID: 19168967

26. Nair AS, Ravindran R, Lakshmanan B, Sreekumar C, Kumar SS, Raju R, et al. Bovine carriers of Anaplasma marginale and Anaplasma bovis in South India. Trop Biomed. 2013; 30(1): 10512. PMID: 23665715

27. Nabian S, Rahbari S. Occurrence of soft and hard ticks on ruminants in Zagros mountainous areas of Iran. Iran J Arthropod Borne Dis. 2008; 2(1): 16-20.

28. Aureli S, Foley JE, Galuppi R, Rejmanek D, Bonoli C, Tampieri MP. Anaplasma phagocytophilum in ticks from parks in the Emilia-Romagna region of northern Italy. Vet ital. 2011; 48(4): 413-23. PMID: 23277122

29. Jahfari S, Coipan EC, Fonville M, Van Leeuwen AD, Hengeveld P, Heylen D, et al. Circulation of four Anaplasma phagocytophilum ecotypes in Europe. Parasit Vectors. 2014; 7: 365. PMID: 25127547

30. Keysary A, Massung RF, Inbar M, Wallach AD, Shanas U, Mumcuoglu KY, et al. Molecular evidence for Anaplasma phagocytophilum in Israel. Emerg Infect Dis. 2007; 13(9):1411-12. PMID: 18252125 